\title{
Coming of age: reconstruction of heterosexual HIV-1 transmission in human ex vivo organ culture systems
}

\author{
PJ Southern $^{1}$, JE Horbul ${ }^{1,2}$, BRL Miller $^{1,3}$ and DM Maher ${ }^{1,4}$
}

Heterosexual transmission of human immunodeficiency virus-1 (HIV-1), from men to women, involves exposure to infectious HIV-1 in semen. Therefore, the cellular and molecular processes that underlie HIV-1 transmission are closely interconnected with fundamental principles of human reproductive biology. Human ex vivo organ culture systems allow experimental reconstruction of HIV-1 transmission, using human semen and premenopausal cervicovaginal mucosal tissue, with specific emphasis on the progression from exposure to development of primary HIV-1 infection. Clearly, an isolated piece of human tissue cannot duplicate the full complexity of events in natural infections, but with correct observation of conventional medical and ethical standards, there is no opportunity to study HIV-1 exposure and primary infection in young women. Human mucosal organ cultures allow direct study of HIV-1 infection in a reproducible format while retaining major elements of complexity and variability that typify community-based HIV-1 transmission. Experimental manipulation of human mucosal tissue both allows and requires acquisition of new insights into basic processes of human mucosal immunology. Expanding from the current foundations, we believe that human organ cultures will become increasingly prominent in experimental studies of HIV-1 transmission and continuing efforts to prevent HIV-1 infection at human mucosal surfaces.

\section{INTRODUCTION}

The molecular virology underlying human immunodeficiency virus-1 (HIV-1) infection has been elegantly described over many years, and a fundamental understanding of the HIV-1 virus replication cycle in infected CD $4+\mathrm{T}$ cells ${ }^{1}$ has been critical in the development of inhibitory drugs that are used for current antiretroviral therapy (ART). ${ }^{2}$ Important ongoing molecular studies are continuing to reveal complexities in the HIV-1 infectious process-such as the interplay between HIV-1-encoded accessory proteins and host-encoded proteins, ${ }^{3-5}$ with implications for the development of new classes of anti-HIV-1 agents. However, progress has been more limited in the acquisition of fundamental understanding of the biological events surrounding HIV-1 transmission and primary infection that could be used to guide the development of vaccines and/or microbicides to protect against mucosal exposure and initiation of HIV-1 infection. ${ }^{6}$ Basic studies on virus transmission have been conducted in primate hosts, principally in rhesus macaques (Macaca mulatta), using simian immunodeficiency virus (SIV) and a vaginal route of infection of female animals, which resembles heterosexual HIV-1 transmission into young women. ${ }^{7,8}$ The SIV/macaque model has been especially useful for studies of virus amplification and dissemination from sites of initial infection, virus replication in lymphoid tissue, and disease progression as CD4 + T-cell numbers decline. However, there are many important biological differences between human HIV-1 heterosexual transmission and experimental SIV infection of female rhesus macaques, relating to exposure to semen and frequency of unprotected intercourse, sexually transmitted infections, and extended use of hormonal contraceptives, which affect mucosal barrier function and overall cellularity in the female reproductive tract (FRT).$^{9-13}$ Although these human variables cannot be easily controlled, variability from person to person must be recognized as a major component influencing primary HIV-1 infection in young women, so that comprehensive protective strategies can be designed

${ }^{1}$ Department of Microbiology, University of Minnesota, Minneapolis, Minnesota, USA. ${ }^{2}$ Present address: University of Wisconsin Hospital and Clinics, Madison, Wisconsin, USA. ${ }^{3}$ Present address: Department of Pathology, Ohio State University, Columbus, Ohio, USA. ${ }^{4}$ Present address: Cancer Biology Research Center, Sanford Research USD, Sioux Falls, South Dakota, USA. Correspondence: PJ Southern (south003@umn.edu) 
with a complete awareness of the biological reality of the human condition.

On one level of understanding, the mechanism of heterosexual HIV-1 transmission from an HIV-1-infected male donor to an uninfected female recipient is well defined: infectious HIV-1 shed in semen is deposited onto mucosal surfaces in the FRT and primary HIV-1 infection becomes established in mucosaassociated leukocytes. ${ }^{14-16}$ However, there are multiple variables relating to both the male infected donor and the female recipient that profoundly affect the transmission process. It has been estimated that male-to-female HIV-1 transmission occurs for 1 in 200 to 1 in 1,000 unprotected exposure events. ${ }^{17,18}$ However, it is clear that a single exposure can be sufficient to transfer infection and that high viral loads in semen have been associated with increased risk of transmission. ${ }^{19}$ There is considerable uncertainty regarding the sources of infectious HIV-1 in the male reproductive tissue: some HIV-1-infected men shed infectious HIV-1 virions in semen, whereas other infected men shed HIV-1-infected cells in semen. ${ }^{20-25}$ Depending on ART status, the highest levels of HIV-1 infectivity (cell-free infectious virions or cell-associated infectivity in the form of infected cells) are detected in semen in the interval after seroconversion. As blood viral loads decrease in response to adaptive anti-HIV-1 immune responses, so do semen viral loads. Early intervention with ART would have an immediate impact in decreasing blood viral loads, and a somewhat slower impact in decreasing semen viral loads. ${ }^{26}$ In the exposed female recipient, multiple variables relating to the integrity of epithelial surfaces have been recognized, which affect susceptibility to primary HIV-1 infection. ${ }^{9}$ In the FRT, pre-existing physical damage caused by trauma during intercourse $\mathrm{e}^{27-29}$ or by independent ongoing viral infections (herpes simplex viruses types 1 or 2) can disrupt the integrity of the mucosal epithelium and allow direct contact between sources of HIV-1 infectivity and leukocytes in the submucosa. ${ }^{30}$ Independently, or in addition, relatively common conditions such as bacterial vaginosis ${ }^{31-33}$ or vaginal candidiasis ${ }^{34,35}$ may contribute to mucosal inflammation and cause profound alterations in the vaginal microenvironment by displacing commensal Lactobacillus spp. and by increasing the basal $\mathrm{pH}$ from the standard acidic range, $\mathrm{pH} 4-5$, toward neutrality.

Unprotected intercourse has also been recognized as contributing to FRT disturbance by triggering rapid recruitment and release of neutrophils across the endocervical epithelium, in a process that has been linked to the removal of excess spermatozoa. Neutrophil recruitment after unprotected intercourse is not easily studied in young women, ${ }^{36}$ but has been investigated extensively in the context of animal artificial insemination programs. ${ }^{37,38}$ Mild-to-moderate cervicitis is commonly observed in sexually active young women in whom inflammatory infiltrates may be quite localized or diffusely distributed in the submucosa. ${ }^{39-41}$ The submucosal infiltrates consist of variable leukocyte populations, but activated CD4 + T cells are consistently detected in proximity to the luminal surface. Multiple mechanisms have been proposed to explain HIV-1 transfer across an apparently intact epithelial barrier: infection of activated Langerhans cells (LCs), ${ }^{42,43}$ infection of macro-

\section{Table 1 Ex vivo HIV-1 infection in human cervicovaginal organ cultures: short-term experiments focusing on HIV-1 transmission and primary infection}

\author{
Significant research benefits \\ Ostensibly normal human premenopausal tissue for direct \\ experimentation \\ Reconstruction of natural routes of human exposure and \\ primary infection \\ Design and evaluation of anti-microbial strategies with \\ human target cells \\ Foundation to study microbial synergy in human polymicrobial \\ infections \\ Insights relate to human condition and human susceptibility \\ to infection
}

Concerns and limitations of current human organ culture systems
Tissue availability
Donor-to-donor variability
Retention of tissue architecture/cell viability for duration of
organ culture

Abbreviation: HIV-1, human immunodeficiency virus-1.

No opportunity to study dissemination of HIV-1 infection and disease progression.

No opportunity to study immune cell recruitment from distal sites.

These issues are deliberately excluded from the current experimental format because of requirements for longitudinal access to patient materials and/or access to primate infection models.

The absence of immune cell recruitment does allow local events at the portal of entry to be studied without the impact or influence of cells from distal sites.

phages, ${ }^{44}$ or transcytosis across epithelial cells. ${ }^{45}$ However, if the epithelial barrier has been damaged, then it is unnecessary to invoke any of these active mechanisms to explain how HIV-1 infectivity might come into direct contact with susceptible $\mathrm{CD} 4+\mathrm{T}$ cells in the submucosa.

This review presents a general rationalization for the research opportunities provided by ex vivo experiments with human mucosal tissues (Table 1). The underlying premise is that acquisition of fundamental information relating to primary HIV-1 transmission can best be derived from direct study of the components of human tissue systems. Clearly, it is totally inconceivable to contemplate deliberate exposure and infection of human patients. Any patient seeking medical advice because of potential exposure to HIV-1 is likely to be offered ART immediately, in conjunction with future serological testing to determine whether seroconversion has actually occurred. Therefore, the opportunities to study HIV-1 exposure and primary infection in patients are severely limited by medical considerations, but the development of ex vivo human organ culture systems has created a valuable experimental platform for direct study of heterosexual transmission of HIV-1 in the human system.

\section{BASIC EPITHELIAL STRUCTURES}

The cellular composition and histological structure of epithelial surfaces in the adult human premenopausal FRT vary according to anatomical location, hormonal signals relating to 
a

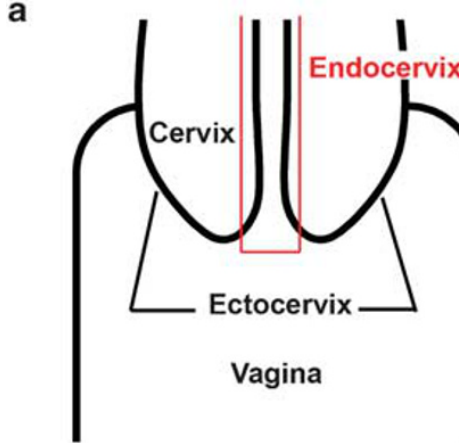

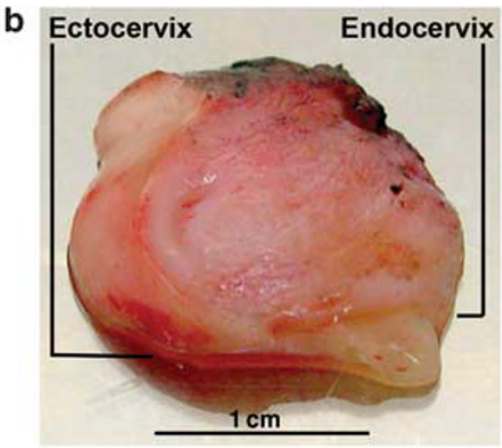

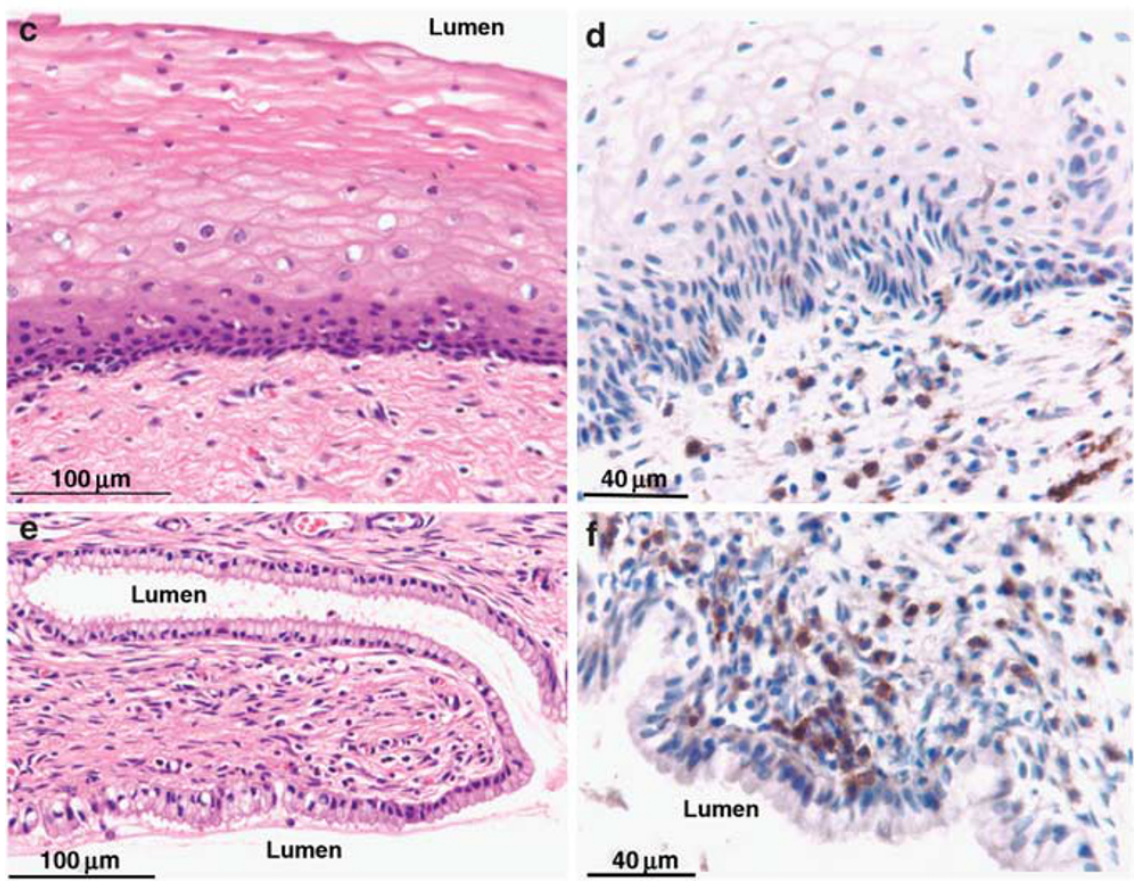

Figure 1 Representations of "normal" human premenopausal cervicovaginal tissue. (a) Line drawing of the head of the vaginal vault and the uterine cervix in a longitudinal section. (b) Typical wedge-shaped cervicovaginal tissue sample. (c) Hematoxylin and eosin (H\&E) staining to show the multi-layered stratified squamous epithelium of the ectocervix. (d) Immunocytochemical (ICC) detection of CD4+ T cells (brown stain) situated just beneath the basal cell layer of the ectocervical epithelium. CD4 + T cells are the primary target cells for HIV-1 infection. Hematoxylin counterstain reveals all cell nuclei (blue). (e) H\&E staining to show the single cell layer columnar epithelium of the endocervix. (f) ICC detection of CD4+ T cells (brown stain; cell nuclei counterstained blue with hematoxylin) situated immediately beneath the columnar epithelium of the endocervix. HIV-1, human immunodeficiency virus-1.

the menstrual cycle, and parity (child-bearing history). ${ }^{15}$ The vaginal walls are composed of a multi-layered stratified squamous epithelium. The outermost cell layers contain dead and dying cells with a high glycogen content that are sloughed away and continuously replaced by outward displacement of terminally differentiated cells from below. Cell proliferation is confined to the suprabasal cell layer-cells situated immediately above the continuous basal cell layer. ${ }^{46}$ Typically, the vaginal epithelium is $15-30$ cell layers thick, and at mid-cycle, during the interval of maximum fertility, the luminal surface is usually coated with a surface layer of keratin. The multi-layered stratified squamous epithelium of the vaginal walls creates a continuous surface with the ectocervical epithelium, although there is generally less variability in the thickness of the ectocervical epithelium, and the surface layers of the ectocervical epithelium may not become keratinized. In the vicinity of the cervical os, the lower opening into the uterine cervix, the mucosal surface changes abruptly into a single cell layer columnar epithelium that defines the anatomical endocervix. The boundary between the stratified squamous epithelium of the ectocervix and the columnar epithelium of the endocervix is known as the cervical transformation zone. The positioning of the cervical transformation zone relative to the cervical os varies according to age, hormonal signals, and pregnancy. Around the time of menarche, $80-90 \%$ of adolescent girls exhibit cervical ectopy, a normal condition in which the columnar epithelium extends beyond the cervical os. ${ }^{47,48}$ Over time, the external areas of the columnar epithelium are gradually replaced by the stratified squamous epithelium such that the columnar epithelium is typically confined to the endocervical canal in young adult women (Figure 1). Cervical ectopy also occurs during pregnancy with restoration of the stratified squamous epithelium after delivery. 
Tissue surface remodeling is associated with active epithelial cell proliferation, with the practical consequence that the cervical os and transformation zone are routinely sampled using a cytological brush to collect cells for Papanicolaou smear tests and for visualization of aberrant cell morphologies. Dysplastic changes in the transformation zone are the first recognized signs of human papilloma virus infections that may progress to cervical carcinoma. ${ }^{49,50}$

In considering the protective capabilities of FRT mucosal barriers, the single columnar epithelial cell layer of the endocervix would appear to be more vulnerable to infection than the multi-layered epithelial surfaces of the vaginal walls and ectocervix. The transient condition of cervical ectopy, in which the columnar epithelium extends beyond the cervical os, ${ }^{47,48}$ may account for the particular susceptibility to HIV-1 reported for adolescent young women who may be coerced into early sexual activity by cultural practices, including marriage early in life. ${ }^{51-54}$ In addition, the common occurrence of mild-tomoderate cervicitis in sexually active young women results in the placement of inflammatory cells, including activated CD4+ $\mathrm{T}$ cells in close proximity to the mucosal surface with the consequence that HIV-1 virions and/or HIV-1-infected cells may only need to penetrate 1-5 cell layers to encounter susceptible target cells (most probably CD4 + CCR $5+\mathrm{T}$ cells) beneath a columnar epithelial surface. ${ }^{39,55}$ Infection may also occur across a stratified squamous epithelial surface ${ }^{56-58}$ where the likelihood of infection would increase with epithelial thinning or with epithelial damage, as might arise from physical trauma or unrelated microbial infections. Small numbers of CD4+ $\mathrm{T}$ cells can be observed, either spread diffusely or localized to one particular site, within or immediately beneath intact stratified squamous epithelial structures, presumably reflecting previous or ongoing immune responses. More highly organized arrangements of leukocytes, tertiary lymphoid structures, are periodically detected in the submucosa of the vagina and ectocervix, ${ }^{59}$ but the signals required to establish and potentially disaggregate these structures currently remain unclear. Collectively, recognition of extensive structural variability across and immediately beneath a mucosal tissue surface leads to the realization that susceptibility to HIV-1 infection may also be highly variable across this tissue surface.

Various studies, extending from vaginal infections of hysterectomized female macaques ${ }^{60}$ to human ex vivo organ cultures discussed here, have demonstrated that SIV or HIV-1 infection can occur across the stratified squamous epithelium of the vaginal walls. ${ }^{6}$ However, these studies do not establish the frequency with which community-acquired HIV-1 infection actually does occur across the vaginal epithelium. If the intact epithelium has been damaged, e.g., by trauma during intercourse, ${ }^{27-29}$ special practices such as "dry sex," ${ }^{1,62}$ or by the presence of herpetic lesions, ${ }^{63}$ then the risk of HIV-1 exposure progressing to primary infection is much increased. LCs and macrophages, both potential targets for HIV-1 infection and/or HIV-1 virion capture or internalization, are randomly distributed in small numbers throughout the stratified squamous epithelium of the vaginal walls and the ectocervix. ${ }^{42-44,64}$ Dendritic processes from LCs extend into the luminal space to capture antigens, and then LC migration to the draining lymph node could trigger a priming reaction for naive $\mathrm{T}$ cells. This normal mechanism of antigen sampling is subverted by HIV-1 under conditions of LC activation as LCs become susceptible to HIV-1 infection and may facilitate establishment of primary infection by virus amplification and subsequent transmission to CD4+ T cells. ${ }^{42,43}$ It is also possible that macrophages within stratified squamous epithelial membranes could support an initial round of HIV-1 infection immediately after exposure, but it remains unclear how localized infection in macrophages might be further amplified.

\section{IMMUNE COMPONENTS AT EPITHELIAL SURFACES Innate immunity}

A wide variety of innate protective mechanisms have been described at epithelial surfaces, ${ }^{65-68}$ but just as there are key structural differences in epithelial composition so there is corresponding variability in the subset of innate components that might function at any given epithelial surface (Table 2). Protective mechanisms can be divided between secreted components (such as mucus, complement, defensins, lactoferrin, lysozyme, secretory leukocyte protease inhibitor), cell-associated components (such as cell surface cilia and pattern-recognition receptors, including Toll-like receptors and C-type lectins, such as Langerin and DC-SIGN), and inducible secreted components (such as interleukin-6, interleukin-8, macrophage inflammatory protein- $3 \alpha$, and interferon- $\alpha$ ). Different assays have been developed to show protective efficacy in the context of carefully defined in vitro systems. However, assays showing biochemical inhibition of HIV-1 infection in a cell culture system using defined medium and immortalized mammalian cells may have only limited connection to the biological reality of HIV-1 infectivity in semen that is coating mucosal surfaces in the human FRT. These concerns are well illustrated by the finding of a correlation between genital infections, leading to induction of $\alpha$-defensins and LL-37 and an increased risk of HIV-1 infection. ${ }^{69}$ It is also likely that there will be quantitative and qualitative differences in innate immune responses across different populations that, at least in part, will reflect individual behavior patterns within any susceptible group and past/ongoing FRT exposure to microbial agents. The overall uncertainty surrounding innate protective components is highlighted by the disturbing conclusion that innate components were seemingly insufficient to protect individuals exposed to HIV-1, which constitute the $\sim 3,500$ new infections occurring daily in young women.

In experimentally infected female macaques, an "outside-in" mechanism of innate signaling has been recognized whereby initial exposure to a high-titer cell-free SIV inoculum triggers induction of macrophage inflammatory protein- $3 \alpha$ and the subsequent recruitment of plasmacytoid dendritic cells to mucosal surfaces. ${ }^{70}$ Further signaling through plasmacytoid dendritic cell-derived interferon- $\alpha$ has been proposed as a mechanism that recruits new target cells into the submucosa with the consequence of amplifying local SIV replication. These results lead 
Table 2 Mucosal cells involved with HIV-1 (SIV) exposure and primary infection

\begin{tabular}{|c|c|c|c|}
\hline Macrophages & Human & $\begin{array}{l}\text { Patient samples, monocyte-derived } \\
\text { macrophages from PBMC }\end{array}$ & $\begin{array}{l}\text { Susceptible to HIV- } 1 \text { infection } \\
\text { Possible long-term reservoir of virus infection }{ }^{44}\end{array}$ \\
\hline Dendritic cells (DCs) & Human & $\begin{array}{l}\text { Primary cell populations, organ } \\
\text { culture }\end{array}$ & $\begin{array}{l}\text { Virus transfer to draining lymph nodes, cytokine/ } \\
\text { chemokine release }{ }^{64,172}\end{array}$ \\
\hline $\begin{array}{l}\text { Langerhans cells } \\
\text { (LCs) }\end{array}$ & Human & $\begin{array}{l}\text { Primary cell populations, organ } \\
\text { culture }\end{array}$ & $\begin{array}{l}\text { Virus uptake across stratified squamous epithelial } \\
\text { surfaces } \\
\text { Cytokine/chemokine release } \\
\end{array}$ \\
\hline Epithelial cells & Human & $\begin{array}{l}\text { Primary cell populations, immortalized } \\
\text { cells }\end{array}$ & $\begin{array}{l}\text { Transcytosis, possible transit reservoir, cytokine/ } \\
\text { chemokine release } 45,65,188\end{array}$ \\
\hline CD8 + T cells (CTLs) & Human & Patient samples & Protection—lysis of infected host cells 7,189 \\
\hline $\begin{array}{l}\text { Natural killer (NK) } \\
\text { cells }\end{array}$ & Human & $\begin{array}{l}\text { Patient samples, ex vivo stem } \\
\text { cell derived (iPSCs and hESCs) } \\
\text { populations }\end{array}$ & Protection-lysis of infected host cells $87,88,90$ \\
\hline$\gamma \delta$ T Cells & Human, Macaque & Patient samples & $\begin{array}{l}\text { Innate immune function in stratified squamous } \\
\text { epithelium }{ }^{43}\end{array}$ \\
\hline $\begin{array}{l}\text { Regulatory T cells } \\
\text { (Tregs) }\end{array}$ & Macaque & SIV-infected macaques & Downmodulation of anti-SIV CTL responses ${ }^{190}$ \\
\hline Stromal cells & Human & Primary cell populations & $\begin{array}{l}\text { Possible target/reservoir for HIV-1 infection } \\
\text { Cytokine/chemokine release }\end{array}$ \\
\hline Neutrophils & Human & Patient samples & $\begin{array}{l}\text { Recruited by epithelial stress responses and } \\
\text { semen }^{36,191}\end{array}$ \\
\hline $\begin{array}{l}\text { Plasmacytoid } \\
\text { dendritic cells (pDCs) }\end{array}$ & Human, Macaque & $\begin{array}{l}\text { Patient samples, SIV-infected } \\
\text { macaques }\end{array}$ & $\begin{array}{l}\text { Recruited by epithelial stress responses } \\
\text { Cytokine release }\end{array}$ \\
\hline
\end{tabular}

Abbreviations: hESC, human embryonic stem cell; HIV-1, human immunodeficiency virus-1; iPSC, induced pluripotent stem cell; PBMC, peripheral blood mononuclear cell; SIV, simian immunodeficiency virus.

to the counterintuitive conclusion that downmodulation of a local innate response may contribute to increased protection against mucosal challenge, and studies are ongoing to understand the immunomodulatory properties of glycerol monolaurate, the agent used in these macaque studies. ${ }^{70}$ There is no clear indication of the extent to which "outside-in" innate signaling may apply to sexually active young women, given the common occurrence of cervicitis and the finding of numerous plasmacytoid dendritic cells in proximity to the mucosal surface and distributed throughout the submucosa of the endocervix (JE Horbul, SC Schmechel, BRL Miller, SA Rice, and PJ Southern, unpublished data). In addition, exposure to seminal plasma has been shown to induce macrophage inflammatory protein-3 $\alpha$ (CCL20) secretion from epithelial cells, ${ }^{71,72}$ suggesting that frequent unprotected intercourse would repeatedly signal for plasmacytoid dendritic cell recruitment to the endocervical surface.

Multiple studies have attempted to define correlates of induced immunity leading to protection from SIV challenge in immunized macaques ${ }^{73-77}$ or that might account for protection in women who are known to have been exposed to HIV-1 but who show no evidence of seroconversion, ${ }^{78}$ or in women who stringently control HIV-1 replication in the absence of ART. ${ }^{79-81}$ It is reasonable to infer that innate components may have exerted protective effects, but this is difficult to quantify other than by comparison with groups of women at very low risk for repeated HIV-1 exposure. Furthermore, protective mechanisms that have been identified in the macaque system may not be equally applicable in the human FRT, as shown by a nonsense mutation in the coding sequence for human $\theta$-defen $\sin ^{82,83}$ and a single amino-acid change in human tripartite motif protein $5 \alpha$ that eliminates the anti-HIV-1-inhibitory activity demonstrated by simian tripartite motif protein $5 \alpha^{84-86}$

The connections between natural killer (NK) cells and virus infection have been studied in many different systems, but there is now increasing interest to evaluate NK-mediated protection against HIV-1 infection. ${ }^{87,88}$ Experimental NK studies have been propelled by recent findings that human NK-like cells can be derived from human embryonic stem cells. ${ }^{89} \mathrm{NK}$ cell populations from human embryonic stem cells or from induced pluripotent stem cells, may have therapeutic application in control of ongoing HIV-1 infection because in vitro studies have shown suppression of HIV-1 infection by three different mechanisms: direct lysis of HIV-1-infected cells, antibody-dependent cellular cytotoxicity, and through production of chemokines and cytokines. ${ }^{90}$ It is also conceivable that induction and expansion of NK populations at exposed FRT mucosal surfaces could contribute directly to resistance to HIV-1 infection by elimination of infected cells before amplification and virus dissemination can occur. 


\section{Adaptive immunity}

The distribution of cellular and soluble components from the adaptive immune system is likely to be highly variable at mucosal surfaces within the FRT, in part because of the variable composition and distribution of inflammatory cell infiltrates (Figure 1, Table 2). There is some evidence suggesting that regulatory $\mathrm{T}$ cells may modulate antigen-specific mucosal immune responses leading to an unpredictable outcome: restricted numbers of available target cells could delay or prevent the establishment of primary infection, ${ }^{91}$ whereas restricted numbers of antigen-specific cells at the portal of entry could facilitate the establishment of primary infection. ${ }^{92}$ At present, basic characterization of human, antigen-specific regulatory $\mathrm{T}$ cells and signals to induce or to expand regulatory $\mathrm{T}$ cell activity at mucosal surfaces remain in the very earliest stages of investigation. ${ }^{93}$ The presence of any type of HIV-1-antigen-specific cells in proximity to mucosal surfaces in women who would conventionally be described as seronegative implies previous exposure to HIV-1, without the establishment of disseminated infection. Groups of women working in the sex trade in Nairobi have been identified, who remained seronegative despite repeated exposure to HIV-1. ${ }^{78}$ The immunological basis for this sustained protection from infection seems to involve both anti-HIV-1-specific sIgA ${ }^{94-97}$ and anti-HIV-1-CD8 + T cells (CTLs). ${ }^{98}$ Tragically, a change in lifestyle for some members of this group of Kenyan women, resulting in much reduced probable exposure to infectious sources of HIV-1, subsequently led to the establishment of HIV-1 infection and seroconversion. ${ }^{99}$ Other studies, based on different groups of exposed and non-infected women, have confirmed the importance of mucosal IgA, ${ }^{100}$ failed to detect specific mucosal antibody responses, ${ }^{101}$ or concluded that immunological protection against systemic infection was provided by mucosal HIV-1-specific IgG. ${ }^{102}$ No immediate resolution has been proposed for the divergence in findings that has been attributed to either mucosal $\operatorname{IgA}$ or $\operatorname{IgG}{ }^{66,103}$

\section{PROGRESSION FROM HIV-1 EXPOSURE TO PRIMARY HIV-1 INFECTION}

In experimental FRT infections, there is a delay between virus exposure and detection of newly infected cells. This finding applies to ex vivo human organ cultures and vaginal infections of macaques - in both HIV-1 and SIV infections, an interval of 3-5 days is required for consistent detection of newly infected cells by in situ hybridization or immunocytochemistry. ${ }^{92,104,105}$ However, a sequence of events ultimately leading to infection, resistance to infection, or failure to establish infection will probably be initiated as soon as the infectious inoculum comes into proximity to the mucosal surface. In the SIV-female macaque system, a vaginal douche has been used shortly after high-dose SIV exposure to inactivate SIV virions remaining within the lumen of the FRT or bound to the mucosal surface, and this treatment did not affect the initiation of SIV infection. ${ }^{106}$ These findings indicate that events progressing to primary SIV infection and, by implication, primary HIV-1 infection begin shortly after mucosal exposure in the FRT, but this does not mean that the infectious process always begins immediately. However, recognition that critical events could begin shortly after exposure has established a requirement to consider physical events occurring at exposed mucosal surfaces. Initial events following virus exposure are more likely to be influenced by principles of biophysics - movement, trapping, and binding of particles in a complex fluid distributed across irregular surfaces-than by recognized mechanisms of molecular virology. We have used a multi-microscope approach to visualize a dynamic sequence of events that occurs when $\mathrm{HIV}-1$ virions or $\mathrm{HIV}$-1-infected cells are deposited onto intact human epithelial surfaces. ${ }^{105,107}$ In many experiments, fluorescently labeled latex particles $(0.1$ and $4.0 \mu \mathrm{m}$ diameter spheres; Invitrogen: Molecular Probes, Eugene, OR; approximate representations of HIV-1 virions and HIV-1-infected lymphocytes, respectively) have been used to demonstrate that inert particles readily interact with mucosal surfaces in the FRT. Surface binding and tissue penetration were examined by time-lapse confocal microscopy, using fresh unfixed human tissues that contained live cells. Subsequently, after tissue fixation and processing, thin sections cut with known orientation from the same tissue pieces were examined by conventional light or fluorescence microscopy, at high resolution. By image analysis, it was possible to enumerate virus particles and cells that remained tightly bound to epithelial surfaces after extensive washing, and this has been used for quantitative assessment of inhibition of HIV-1 virion binding. ${ }^{105}$ In addition, it is now possible to visualize interactions between different classes of microbes at epithelial surfaces and to investigate the cellular and molecular basis for any increased susceptibility to infection (microbial synergy), when multiple microbes are present $^{108-110}$ (JE Horbul, SC Schmechel, BRL Miller, SA Rice, and PJ Southern, unpublished data).

\section{VARIABILITY AND HETEROGENEITY AT MUCOSAL SURFACES}

The mucosal surfaces of the premenopausal FRT are directly responsive to hormonal signals throughout the menstrual cycle. Around the time of ovulation in mid-cycle, the outermost layers of the vaginal epithelium can develop a surface layer of keratin. This cyclical change has been rationalized as a mechanism to protect the vaginal walls from trauma during intercourse, occurring during the short interval of maximum female fertility. Concurrently, mucus secretion from the endocervical epithelium changes such that mid-cycle mucus is highly hydrated (viscosity is at the lowest level), ${ }^{111}$ presumably to facilitate movement of spermatozoa through the endocervical canal and into the fallopian tubes. There is a clear protective role for mucus in preventing direct contact with the epithelial cell surface, but particles suspended in mucus may remain in proximity to the epithelial cell surface for extended intervals, ${ }^{105}$ increasing the likelihood that specific binding to the surface may then follow. Recent studies have recorded a 60-70-fold increase in the diffusion rate for HIV-1 virions in cervical mucus that is associated with an increase from approximately $\mathrm{pH} 4$ to approximately pH6, as would occur immediately after intermixing of mucus and semen. ${ }^{112}$ These findings emphasize the dynamic nature of interactions between components of semen, including HIV-1 
infectivity, and mucosal surfaces in the FRT and indicate that further studies involving semen and mucus are warranted. ${ }^{113}$

\section{ANALYTICALTOOLS: SINGLE CELL DETECTION TECHNOLOGIES}

Heterogeneity in tissue microarchitecture that is typically present at mucosal surfaces has the potential to create technical challenges for experimental analyses in which events within one cell may be substantially affected by the surrounding cells. The importance of hierarchical interactions is best appreciated by single-cell analytical methods-in situ hybridization and immunocytochemistry-in which the anatomical context of infected cells can be readily visualized. ${ }^{104}$ These procedures require considerable time and skill to retrieve high-quality information under optimized conditions. Multiple sections must be surveyed to develop a comprehensive reconstruction of exposure/infection at the mucosal surface. As an independent experimental approach, several different procedures have been developed for enzymatic digestion of mucosal tissues for subsequent analysis of single cell suspensions or nucleic acid and protein extractions. ${ }^{114,115}$ However, all of these disruption and extraction procedures eliminate spatial information in which, at least during exposure, proximity to the mucosal surface will dramatically increase the likelihood of involvement in the initiation of infection. The power and efficiency of delineating functional cell populations by fluorescence activated cell sorting are undermined by the absence of information relating to location, and if the sorting parameters are set to exclude multi-cell complexes, any functional detail relating to cell-cell interactions may be overlooked.

Refinements to the well-established in situ hybridization and immunocytochemistry single cell analytical procedures include in situ tetramer hybridization ${ }^{116}$ and laser capture microdissection (LCM) ${ }^{117}$ In situ tetramer hybridization allows visualization of the juxtaposition of antigen-specific CTLs, detected by tetramer staining of CTLs recognizing immunodominant epitopes $^{73}$ and virus-infected cells, visualized by conventional in situ hybridization procedures. Application of in situ tetramer hybridization to mucosal and lymphatic tissue samples from acute SIV infections has revealed low in vivo effector-to-target ratios $(<2)$ for SIV-specific CTLs recognizing immunodominant epitopes, and provides an immunological explanation for the inability of primary SIV-specific CTL responses to contain the SIV infection. ${ }^{7,116}$ LCM involves brief antibody staining of frozen or fixed tissue sections, followed by laser capture of microscopically selected areas that are then extracted to obtain minute amounts of nucleic acid for reverse transcription-PCR or PCR amplification or used for direct protein analysis. ${ }^{117}$ Individual infected cells have been identified in HIV-1-infected brain sections by LCM analysis, ${ }^{118}$ and it seems probable that new insights will emerge from LCM-based studies of exposed mucosal surfaces. Although in situ tetramer hybridization and LCM are technically demanding, these procedures provide valuable opportunities to derive molecular and cellular information relating to function, which can be superimposed onto a spatial framework.
A number of organ culture studies based on punch biopsies (typically $5 \mathrm{~mm}$ ) or cut tissue blocks taken from the same surgical tissue sample have established biochemical outcomes for induction of changes in host cells or HIV-1 infection by analyzing cytokines, virions, and/or soluble viral proteins that are released into the culture medium. ${ }^{115,119,120}$ Assays based on enzyme-linked immunosorbent assay or multiplex bead procedures to measure soluble antigens, or co-culture with susceptible target cells to demonstrate the presence of infectious HIV-1 yield quantitative information, but a key biological element is missing in terms of identifying the cell type and physical location of the source of target molecules. An additional complication arises from cell loss or active cell emigration from cut tissue surfaces, so that accumulation of soluble components in the culture medium during organ culture incubations needs to be interpreted with caution. More importantly, loss of structural integrity during ex vivo incubations may affect the overall experimental outcome and diminish the connection to an exact reconstruction of HIV-1 transmission at human mucosal surfaces.

\section{PRACTICAL CONSIDERATIONS FOR EXPERIMENTS WITH HUMANTISSUE SAMPLES}

Human tissue samples offer a unique opportunity to introduce an additional experimental resource on the continuum extending from immortalized tissue culture cells through mouse and primate model systems to actual treatment of infected patients. The general strategy, used most widely with palatine tonsil, rectal, and FRT mucosal tissues, ${ }^{115}$ has been to collect tissues from uninfected patients for short-term ex vivo HIV-1 exposure and infection studies of events occurring in proximity to mucosal surfaces. To minimize cell emigration, cell death, and overall loss of structural integrity, tissue samples are evaluated and processed with the shortest possible delay (Table 3). Every patient and, consequently, every tissue sample can be expected to have unique characteristics. Experience gained from processing a wide variety of human mucosal tissue samples has led to the realization that "normal" defines a range of conditions, in which textbook quality morphology is the exception rather than the rule. This conclusion is well recognized by pathologists but, seemingly, is not fully appreciated in the wider research community. "Normal" morphology equates to a range of variance away from the idealized state and, equally importantly, epithelial surface structure and barrier characteristics may change from normal to abnormal within 50-100 $\mu \mathrm{m}$. Every piece of human tissue is different, and we have evidence from both histological and biochemical analyses that large differences can occur in adjacent regions on the surface of a single piece of tissue. ${ }^{105,107,121}$ These same conclusions regarding tissue variability also apply to macaques. The critical point here is that, although variability in macaque FRT morphology undoubtedly affects macaque susceptibility to SIV infection, ${ }^{63,122-124}$ further insights into the specific events underlying HIV-1 transmission can only be derived by direct analysis of human premenopausal FRT.

A single breach in an otherwise intact epithelial barrier may be all that is required to allow initiation of primary HIV-1 infection. Independent analyses involving both HIV-1-infected 
Table 3 General scheme for routine processing of human FRT tissue

Tissue stored at $4^{\circ} \mathrm{C}$ after processing in a surgical pathology
laboratory
Tissue collected and examined macroscopically as soon as
possible
Tissue photographed and evaluated_-mucus removed for wet
mount examination
Tissue cut and processed for organ culture infections/disruption/
fixation

Infections generally initiated within 4-6h of completion of surgery (tissue that cannot be processed without delay is generally not used for infection)

Regular monitoring of organ cultures to maintain moist mucosal surfaces

Tissues fixed and processed according to pre-determined protocols

Abbreviation: FRT, female reproductive tract.

Complete experimental control resides within the primary laboratory, including immediate design revision and/or termination in response to unexpected developments.

patients and experimentally infected female macaques support the interpretation that infection may be initiated at a single location within the FRT. Molecular techniques based on singlegenome sequencing have clearly demonstrated that one or very few genomes predominate in the early stages of an expanding infection derived from a complex virus inoculum. ${ }^{125-129}$ The same conclusion is supported by high-dose SIV vaginal infection that, at the single cell level revealed by in situ hybridization, frequently results in one or very few independently established foci of infection. New infections are most commonly first observed within the endocervix, ${ }^{116}$ even though the virus inoculum would have been widely distributed across the mucosal surfaces of the macaque FRT. ${ }^{130}$

Microscopic analysis of appropriately stained tissue sections reveals differences in both structure and function in columnar epithelial cells within small distances across the endocervical surfaces. Structural differences include immediate proximity to leukocytes and the vasculature and lymphatics systems. ${ }^{43}$ Functional differences in columnar epithelial cell membranes are revealed by immunocytochemistry procedures, as individual cells show cell-by-cell variability. ${ }^{70}$

Additional elements of variability and complexity may arise from the non-uniform distribution of commensal organisms and/or opportunistic pathogens across the FRT mucosal surfaces. The medium for ex vivo organ cultures usually includes antibiotics and an anti-fungal compound to prevent outgrowth of agents that were naturally present at the mucosal surface and adventitious air-borne contaminants. ${ }^{105,115}$ Under these conditions, there is still the opportunity, or unavoidable necessity, of considering mitogenic or other stimulatory or inhibitory signals delivered by killed organisms to target human cells.

Over the time course of ex vivo incubations, several types of changes have been noted in FRT mucosal tissues that may affect experimental outcome. The integrity of stratified squamous epithelial surfaces is usually not well maintained as the most external cell layers rapidly detach and the entire epithelial layer may separate away, leaving only the basal cell layer at the surface of the tissue piece. ${ }^{131}$ Conversely, endocervical tissue surfaces usually maintain cell viability with good preservation of structural integrity in organ cultures up to 7 days. ${ }^{132}$ Endocervical columnar epithelial cells frequently secrete mucus that coats the tissue surface, and mucus probably contributes directly to retention of cell viability. In addition, a form of epithelial cell repair occurs at cut tissue surfaces with initial proliferation of highly elongated cells that create a new surface layer (PJ Southern, unpublished observations for the endocervix; epithelial surface repair for palatine tonsil samples in organ culture has been documented previously ${ }^{107,121,133}$ ). Changes in both cell composition and cell function that occur during ex vivo incubations may affect biochemical outcomes relating to primary HIV-1 infection, but these parameters can only be assessed with inclusion of histological analyses of tissue samples on termination of experimental incubations. ${ }^{131,132}$

\section{Model systems using mixed human cell populations}

During the recent development phase of human ex vivo organ culture systems, several other experimental resources have been created with the goal of expanding opportunities for basic HIV-1 research. Mice have been generated by transplantation technologies that maintain human adaptive immune system components including CD4 + T cells that support HIV-1 replication. ${ }^{134-136}$ SCID-hu mice (Severe Combined Immunodeficiency-humanized) ${ }^{137,138}$ and BLT mice (Bone Marrow, Liver, Thymus) $)^{139,140}$ are not necessarily optimal for transmission studies because they retain mouse mucosal and stromal components, and natural routes of HIV-1 transmission begin with mucosal exposure. Another interesting approach has seen the development of multi-layered stratified squamous epithelial membranes (MatTek, Boston, MA) that are derived in an ex vivo differentiation system, using human ectocervical epithelial cells ${ }^{141,142}$ or vaginal epithelial cells. ${ }^{143}$ These membrane systems are notable for their highly uniform composition but, with this property, there is considerable departure from the heterogeneity that typifies human FRT mucosal surfaces. Both the reconstructed mouse systems and the differentiated ectocervical membrane system undoubtedly represent valuable technical resources and will continue to be used for HIV-1 exposure/infection studies, but key elements of these models deviate from the known specifics of community-based HIV-1 transmission.

\section{HUMAN SEMEN AS AN ESSENTIAL EXPERIMENTAL COMPONENT}

A compelling argument can be made that heterosexual HIV-1 transmission, from men to women, will almost always involve contact with semen. Therefore, the cellular and molecular processes that underlie heterosexual transmission of HIV-1 can only be fully appreciated in systems that are based on human materials and include components that are normally present in semen. Human semen has been studied for many years, primarily in terms of understanding male fertility and basic reproductive 
biology. ${ }^{144-147}$ A normal, healthy adult man releases approximately 75-100 million viable, motile spermatozoa per milliliter of semen, with a typical ejaculate volume of $2-5 \mathrm{ml}$. In addition, varying numbers of leukocytes, mainly neutrophils with some representation of macrophages and $\mathrm{T}$ cells, and epithelial cells are released in semen. ${ }^{148-150}$ Leukocyte counts in semen in excess of 1 million cells per $\mathrm{ml}$ (a condition defined as leukocytospermia) occur with urinary tract infections and/or with large numbers of defective spermatozoa, linked to male infertility. Under conditions of leukocytospermia, the excess content of leukocytes is composed primarily of neutrophils, but individual patients with strikingly different leukocyte profiles in semen can be identified quite readily. ${ }^{149,151}$ At present, there is only very limited understanding of the processes by which leukocytes enter the male reproductive tract and sources of HIV-1 infectivity that are shed in semen. ${ }^{152,153}$ The cell-free component of semen, seminal plasma, is a protein-rich fluid containing high levels of proteases, esterases, DNases, and phosphatases in addition to various cytokines, complement, prostaglandins, fibronectin, and high levels of zinc ions. ${ }^{154-159}$ Fibronectin is known to bind to gp120 on the virion surface, ${ }^{160}$ and depending on the composition of the viral envelope, other binding interactions involving HIV-1 virions in semen may also occur. ${ }^{161,162}$ In total, semen must therefore be recognized as a highly bioactive fluid with the potential to modify the surface of HIV-1 virions and cause transient changes in the FRT that are induced either by heterologous male cell populations and/or by the mixture of soluble mediators contacting the exposed mucosal surfaces. Additional studies, building on the foundations established for the properties of human cervical mucus, ${ }^{112,163}$ are necessary to clarify the interactions between HIV-1 virions or HIV-1-infected cells suspended in semen and cervical mucus.

During unprotected intercourse, semen is deposited at the head of the vaginal vault in proximity to the cervical os. Spermatozoa may then migrate upward into the endocervical canal. ${ }^{164}$ Fertilization usually occurs within the fallopian tubes, meaning that spermatozoa must ascend through the endocervical canal and traverse the endometrial surface to enter the fallopian tubes. On the basis of measurements of mobility for spermatozoa, this process could be theoretically completed within 10 min but generally may require several hours. ${ }^{165}$ Spermatozoa can remain viable within the FRT, and complete fertilization up to 5 days after intercourse ${ }^{166}$ and motile spermatozoa have been recovered from cervical mucus up to 7 days after intercourse. ${ }^{167}$ In an attempt to conceptualize the details of heterosexual HIV-1 transmission, we consider the distribution and movement of spermatozoa as a surrogate marker for the potential distribution of HIV-1 infectivity across the mucosal surfaces of the FRT. Some studies have reported that spermatozoa may actually be infected with HIV-1 and/or that HIV-1 virions may bind to spermatozoa. ${ }^{168,169}$ Although these findings may not be universally accepted, ${ }^{22,170}$ there is a valuable outcome in forging a clear connection between HIV-1 transmission and reproductive biology. From our own work, we have demonstrated that spermatozoa and HIV-1 virions can independently bind and then penetrate beneath the surface of the stratified squamous epithelium. Surface binding and penetration of foreign cells and particles, namely spermatozoa and male leukocytes and HIV-1 virions, are likely to induce transient changes in FRT epithelial surfaces, with the potential to increase overall susceptibility to primary HIV-1 infection. Equivalent binding and penetration of spermatozoa and HIV-1 virions have also been observed at the endocervical surface, where the limited protective characteristics of the single cell layer columnar epithelium together with the common occurrence of submucosal inflammation appear to create a highly vulnerable site for primary HIV-1 infection. ${ }^{70,105}$

Despite the clear potential for semen to cause transient changes in FRT, there has only been limited consideration of the importance and contribution of co-factors for HIV-1 transmission that could be derived from semen. For example, virions in seminal plasma become coated with fibronectin and then may bind to epithelial cell surface integrins through fibronectin bridges in a process that resembles fibronectin-mediated bacterial binding and internalization by mammalian cells. ${ }^{160,171}$ More recently, two independent studies have concluded that HIV-1 virion binding to DC-SIGN ${ }^{172}$ is substantially reduced in the presence of seminal plasma, bringing into question the contribution of HIV-1 virion capture by DCs as a major mechanism for HIV-1 uptake across mucosal barriers. ${ }^{173,174}$ In another study of physical interactions between HIV-1 virions and semen, amyloid fibrils derived from a peptide fragment of prostatic acid phosphatase in semen were shown to bind HIV-1 virions and to enhance infection of target cells. ${ }^{175} \mathrm{On}$ the basis of this property of influencing HIV-1 infection, amyloid fibrils have been termed "SEVI" (Semen-derived Enhancer of Virus Infection). At present, the biological significance of SEVI remains somewhat difficult to evaluate based on published work conducted in vitro and the apparent requirement for prolonged incubations of seminal plasma at low temperatures to trigger fibril formation. ${ }^{175,176}$ Variable levels of SEVI activity were recently observed within a panel of normal semen donors, ${ }^{177}$ suggesting that amyloid fibrils may be naturally present in semen and therefore available to facilitate HIV-1 transmission in the exposed FRT. The possibilities for additional interactions between HIV-1 virions and semen are further enlarged by the incorporation of hostcell constituents into the HIV-1 envelope. ${ }^{161,162}$ Collectively, the fundamental importance of acquiring new insights into HIV-1 transmission by conducting studies in the presence of human semen is underscored both by these recent findings with SEVI and earlier studies. ${ }^{178-180}$

To facilitate the inclusion of semen or seminal plasma into standard experimental protocols, a series of relatively straightforward handling procedures has been developed. Viable spermatozoa and viable spermatozoa pre-labeled with the fluorescent dye CFSE have been frozen and stored in liquid nitrogen (standard viable cell-freezing protocol) and samples of undiluted cell-free seminal plasma have been stored at $-80^{\circ} \mathrm{C}$. ${ }^{181}$ We have also created a consistent surrogate infectious sample by mixing a low-passage patient isolate stock of HIV-1 (HIV96-480) ${ }^{107}$ with semen or seminal plasma obtained from normal donors. This strategy circumvents the wide variability in cellular content and 


\section{Table 4 Frequent occurrence of STIs in human populations}

\author{
Transmission Documented in Semen: \\ HIV-1, HTLV-I, HBV, HCV, HSV-1, HSV-2, CMV, EBV, HHV-6, KSHV, \\ HPV \\ Chlamydia trachomatis, Neisseria gonorrhoeae, Gardnerella \\ vaginalis \\ Mollicutes sp. (Mycoplasmas) \\ Candida albicans
}

Transmission by Intimate Contact:

HSV-1, HSV-2, HPV

Haemophilus ducreyi, Gardnerella vaginalis, Chlamydia trachomatis

Neisseria gonorrhoeae, Treponema pallidum, Group B

Streptococci

(Mobiluncus?)

Candida albicans, Trichonomas vaginalis, Schistosoma haematobium

Low-Level Commensal Infections with Potential for Pathogenic Expansion:

\section{Staphylococcus aureus, Candida albicans}

Populations of anaerobic bacteria linked to bacterial vaginosis

Interpretations and implications: Male and female reproductive tissues are highly susceptible to microbial infections. Transmission of STIs frequently involves exchange of body fluids. Polymicrobial infections and synergy between microbes may be extensively underrecognized. STI, sexually transmitted infection.

HIV-1 infectivity that has been observed in semen samples from HIV-1-infected donors.

\section{CONCLUSIONS}

Several different groups have published important findings derived from ex vivo FRT human organ culture systems that, cumulatively, validate the feasibility, utility, and overall importance of this experimental approach. ${ }^{56-58,105,182}$ The potential advantages and the unavoidable limitations of the ex vivo systems are now quite apparent (Table 1), and the challenge remains to refine the experimental systems further to derive additional insights into specific events linking HIV-1 exposure and progression to primary infection. This task will undoubtedly require analytical procedures to visualize cell-cell interactions and immunological outcomes for cell populations situated in immediate proximity to human FRT mucosal surfaces. There are continuing applications for organ culture protocols in the realm of microbicide evaluation with respect to both documenting anti-HIV-1-inhibitory effects and minimizing mucosal perturbation that could inadvertently trigger inflammatory responses. ${ }^{183,184}$ Looking further ahead, there may be opportunities to retrieve biopsy samples from vaccinated individuals, so that local innate and adaptive immune responses and resistance to HIV-1 challenge can be directly assessed by ex vivo organ culture. There are also potentially unlimited opportunities to add complexity back into the experimental systems, in the context of HIV-1 infection, in pursuit of a more complete reconstruction of the premenopausal FRT environment. This can be achieved with the inclusion of viable bacteria-commensal Lactobacillus spp. and/or reproductive tract bacterial pathogens, including Staphylococcus aureus, Gardnerella vaginalis, Chlamydia trachomatis, Group B Streptococci, or anaerobic bacterial populations, linked to bacterial vaginosis-exogenous viruses or even eukaryotic microbes. ${ }^{185}$ The principal microbial agents linked to sexually transmitted infections $31,39,153,186,187$ are listed in Table 4, and with well-defined short-term experimental goals, any of these infections can now be usefully studied in ex vivo FRT systems that have been described. On the basis of experiences in the Southern laboratory, most organ culture experiments contribute new information and insights relating to the human condition that were not known before initiation of the experiment.

\section{ACKNOWLEDGMENTS}

We thank our colleagues Drs Ashley Haase, Qingsheng Li, Stefan Pambuccian, Stephen Schmechel, Timothy Schacker, and Patrick Schlievert for their interest and constructive discussions during the development of ex vivo organ culture systems at the $U$ of $M N$ and Dr Stephen McSorley for the original suggestion to write this review. We also acknowledge the insight and commitment of a limited number of pioneers who have established the foundations for research with human organ culture systems, some highly active and leading the field today and others who were more active in previous decades. Our work would not be possible without the invaluable assistance of Ms Sarah Bowell in the Tissue Procurement Facility, a component of BioNet within the University of Minnesota Academic Health Center, and many anonymous patients who have allowed tissue samples to be used for research purposes with Institutional Review Board (IRB) approval. This work was supported in part by National Institutes of Health Grant DE 15090.

\section{DISCLOSURE}

The authors declared no conflict of interest.

(C) 2011 Society for Mucosal Immunology

\section{REFERENCES}

1. Levy, J.A. HIV pathogenesis: 25 years of progress and persistent challenges. AIDS 23, 147-160 (2009).

2. De Clercq, E. Anti-HIV drugs: 25 compounds approved within 25 years after the discovery of HIV. Int. J. Antimicrob. Agents 33, 307-320 (2009).

3. Henriet, S., Mercenne, G., Bernacchi, S., Paillart, J.C. \& Marquet, R. Tumultuous relationship between the human immunodeficiency virus type 1 viral infectivity factor (Vif) and the human APOBEC-3G and APOBEC-3F restriction factors. Microbiol. Mol. Biol. Rev. 73, 211-232 (2009).

4. Holmes, R.K., Malim, M.H. \& Bishop, K.N. APOBEC-mediated viral restriction: not simply editing? Trends Biochem. Sci. 32, 118-128 (2007).

5. Adamson, C.S. \& Freed, E.O. Novel approaches to inhibiting HIV-1 replication. Antiviral Res. 85, 119-141 (2010).

6. Hladik, F. \& McElrath, M.J. Setting the stage: host invasion by HIV. Nat. Rev. Immunol. 8, 447-457 (2008).

7. Haase, A.T. Targeting early infection to prevent HIV-1 mucosal transmission. Nature 464, 217-223 (2010).

8. Haase, A.T. Perils at mucosal front lines for HIV and SIV and their hosts Nat. Rev. Immunol. 5, 783-792 (2005).

9. Galvin, S.R. \& Cohen, M.S. The role of sexually transmitted diseases in HIV transmission. Nat. Rev. Microbiol. 2, 33-42 (2004).

10. Cohen, C.R. et al. Increased levels of immune activation in the genital tract of healthy young women from sub-Saharan Africa. AIDS 24, 2069-2074 (2010).

11. Levine, W.C. et al. Increase in endocervical CD4 lymphocytes among women with nonulcerative sexually transmitted diseases. J. Infect. Dis. 177, 167-174 (1998). 
12. Morrison, C.S. et al. Hormonal contraceptive use, cervical ectopy, and the acquisition of cervical infections. Sex. Transm. Dis. 31, 561-567 (2004).

13. Morrison, C.S. et al. Hormonal contraception and the risk of HIV acquisition. AIDS 21, 85-95 (2007).

14. Royce, R.A., Sena, A., Cates, W. Jr. \& Cohen, M.S. Sexual transmission of HIV. N. Engl. J. Med. 336, 1072-1078 (1997).

15. Coombs, R.W., Reichelderfer, P.S. \& Landay, A.L. Recent observations on HIV type-1 infection in the genital tract of men and women. AIDS 17, 455-480 (2003).

16. Pilcher, C.D. et al. Brief but efficient: acute HIV infection and the sexual transmission of HIV. J. Infect. Dis. 189, 1785-1792 (2004).

17. Gray, R.H. et al. Probability of HIV-1 transmission per coital act in monogamous, heterosexual, HIV-1-discordant couples in Rakai, Uganda. Lancet 357, 1149-1153 (2001).

18. Wawer, M.J. et al. Rates of HIV-1 transmission per coital act, by stage of HIV-1 infection, in Rakai, Uganda. J. Infect. Dis. 191, 1403-1409 (2005).

19. Powers, K.A., Poole, C., Pettifor, A.E. \& Cohen, M.S. Rethinking the heterosexual infectivity of HIV-1: a systematic review and meta-analysis. Lancet Infect. Dis. 8, 553-563 (2008).

20. Crittenden, J.A., Handelsman, D.J. \& Stewart, G.J. Semen analysis in human immunodeficiency virus infection. Fertil. Steril. 57, 1294-1299 (1992).

21. Krieger, J.N. et al. Intermittent shedding of human immunodeficiency virus in semen: implications for sexual transmission. J. Urol. 154, 1035-1040 (1995).

22. Quayle, A.J., Xu, C., Mayer, K.H. \& Anderson, D.J. T lymphocytes and macrophages, but not motile spermatozoa, are a significant source of human immunodeficiency virus in semen. J. Infect. Dis. 176, 960-968 (1997).

23. Fiscus, S.A., Vernazza, P.L., Gilliam, B., Dyer, J., Eron, J.J. \& Cohen, M.S. Factors associated with changes in HIV shedding in semen. AIDS Res. Hum. Retroviruses 14 (Suppl 1), S27-S31 (1998).

24. Vernazza, P.L., Eron, J.J. \& Fiscus, S.A. Sensitive method for the detection of infectious HIV in semen of seropositive individuals. J. Virol. Methods 56, 33-40 (1996).

25. Kiessling, A.A. et al. Human immunodeficiency virus in semen arises from a genetically distinct virus reservoir. AIDS Res. Hum. Retroviruses 14 (Suppl 1), S33-S41 (1998).

26. Zhu, T. et al. Genetic characterization of human immunodeficiency virus type 1 in blood and genital secretions: evidence for viral compartmentalization and selection during sexual transmission. J. Virol. 70, 3098-3107 (1996).

27. Norvell, M.K., Benrubi, G.I. \& Thompson, R.J. Investigation of microtrauma after sexual intercourse. J. Reprod. Med. 29, 269-271 (1984).

28. Sommers, M.S. Defining patterns of genital injury from sexual assault: a review. Trauma Violence Abuse 8, 270-280 (2007).

29. Zink, T., Fargo, J.D., Baker, R.B., Buschur, C., Fisher, B.S. \& Sommers, M.S. Comparison of methods for identifying ano-genital injury after consensual intercourse. J. Emerg. Med. 39, 113-118 (2010).

30. Abu-Raddad, L.J. et al. Genital herpes has played a more important role than any other sexually transmitted infection in driving HIV prevalence in Africa. PloS One 3, e2230 (2008).

31. Fredricks, D.N., Fiedler, T.L. \& Marrazzo, J.M. Molecular identification of bacteria associated with bacterial vaginosis. N. Engl. J. Med. 353, 1899-1911 (2005).

32. Srinivasan, S. et al. Temporal variability of human vaginal bacteria and relationship with bacterial vaginosis. PloS One 5, e10197 (2010).

33. Thurman, A.R. \& Doncel, G.F. Innate immunity and inflammatory response to Trichomonas vaginalis and bacterial vaginosis: relationship to HIV acquisition. Am. J. Reprod. Immunol. 65, 89-98 (2011).

34. Fidel, P.L. Jr. et al. An intravaginal live Candida challenge in humans leads to new hypotheses for the immunopathogenesis of vulvovaginal candidiasis. Infect. Immun. 72, 2939-2946 (2004).

35. Achkar, J.M. \& Fries, B.C. Candida infections of the genitourinary tract. Clin. Microbiol. Rev. 23, 253-273 (2010).

36. Prakash, M., Patterson, S., Gotch, F. \& Kapembwa, M.S. Recruitment of CD4 T lymphocytes and macrophages into the cervical epithelium of women after coitus. Am. J. Obstet. Gynecol. 188, 376-381 (2003).

37. Rozeboom, K.J., Troedsson, M.H. \& Crabo, B.G. Characterization of uterine leukocyte infiltration in gilts after artificial insemination. J. Reprod. Fertil. 114, 195-199 (1998).
38. Alghamdi, A.S. \& Foster, D.N. Seminal DNase frees spermatozoa entangled in neutrophil extracellular traps. Biol. Reprod. 73, 1174-1181 (2005).

39. Lusk, M.J. \& Konecny, P. Cervicitis: a review. Curr. Opin. Infect. Dis. 21, 49-55 (2008).

40. Kaul, R. et al. The genital tract immune milieu: an important determinant of HIV susceptibility and secondary transmission. J. Reprod. Immunol. 77, 32-40 (2008).

41. Kaushic, C., Ferreira, V.H., Kafka, J.K. \& Nazli, A. HIV infection in the female genital tract: discrete influence of the local mucosal microenvironment. Am. J. Reprod. Immunol. 63, 566-575 (2010).

42. de Jong, M.A. \& Geijtenbeek, T.B. Langerhans cells in innate defense against pathogens. Trends Immunol. 31, 452-459 (2010).

43. Iwasaki, A. Antiviral immune responses in the genital tract: clues for vaccines. Nat. Rev. Immunol. 10, 699-711 (2010).

44. Sharova, N., Swingler, C., Sharkey, M. \& Stevenson, M. Macrophages archive HIV-1 virions for dissemination in trans. EMBO J 24, 2481-2489 (2005).

45. Bomsel, M. Transcytosis of infectious human immunodeficiency virus across a tight human epithelial cell line barrier. Nat. Med. 3, 42-47 (1997).

46. Konishi, I., Fujii, S., Nonogaki, H., Nanbu, Y., Iwai, T. \& Mori, T. Immunohistochemical analysis of estrogen receptors, progesterone receptors, Ki-67 antigen, and human papillomavirus DNA in normal and neoplastic epithelium of the uterine cervix. Cancer 68, 1340-1350 (1991).

47. Jacobson, D.L., Peralta, L., Graham, N.M. \& Zenilman, J. Histologic development of cervical ectopy: relationship to reproductive hormones. Sex. Transm. Dis. 27, 252-258 (2000).

48. Moscicki, A.B., Ma, Y., Holland, C. \& Vermund, S.H. Cervical ectopy in adolescent girls with and without human immunodeficiency virus infection. J. Infect. Dis. 183, 865-870 (2001).

49. Castle, P.E. et al. Age-related changes of the cervix influence human papillomavirus type distribution. Cancer Res. 66, 1218-1224 (2006).

50. Schiffman, M., Castle, P.E., Jeronimo, J., Rodriguez, A.C. \& Wacholder, S. Human papillomavirus and cervical cancer. Lancet 370, 890-907 (2007).

51. Quinn, T.C. \& Overbaugh, J. HIV/AIDS in women: an expanding epidemic. Science 308, 1582-1583 (2005).

52. Leclerc, P.M., Matthews, A.P. \& Garenne, M.L. Fitting the HIV epidemic in Zambia: a two-sex micro-simulation model. PloS One 4, e5439 (2009).

53. Carpenter, L.M., Kamali, A., Ruberantwari, A., Malamba, S.S. \& Whitworth, J.A. Rates of HIV-1 transmission within marriage in rural Uganda in relation to the HIV sero-status of the partners. AIDS 13, 1083-1089 (1999).

54. Moss, G.B. et al. Association of cervical ectopy with heterosexual transmission of human immunodeficiency virus: results of a study of couples in Nairobi, Kenya. J. Infect. Dis. 164, 588-591 (1991).

55. Stern, J.E., Givan, A.L., Gonzalez, J.L., Harper, D.M., White, H.D. \& Wira, C.R. Leukocytes in the cervix: a quantitative evaluation of cervicitis. Obstet. Gynecol. 91, 987-992 (1998).

56. Greenhead, P., Hayes, P., Watts, P.S., Laing, K.G., Griffin, G.E. \& Shattock, R.J. Parameters of human immunodeficiency virus infection of human cervical tissue and inhibition by vaginal virucides. J. Virol. 74, 5577-5586 (2000).

57. Collins, K.B., Patterson, B.K., Naus, G.J., Landers, D.V. \& Gupta, P. Development of an in vitro organ culture model to study transmission of HIV-1 in the female genital tract. Nat. Med. 6, 475-479 (2000).

58. Hladik, F. et al. Initial events in establishing vaginal entry and infection by human immunodeficiency virus type-1. Immunity 26, 257-270 (2007).

59. Kobayashi, A. et al. Lymphoid follicles are generated in high-grade cervical dysplasia and have differing characteristics depending on HIV status. Am. J. Pathol. 160, 151-164 (2002).

60. Miller, C.J., Alexander, N.J., Vogel, P., Anderson, J. \& Marx, P.A. Mechanism of genital transmission of SIV: a hypothesis based on transmission studies and the location of SIV in the genital tract of chronically infected female rhesus macaques. J. Med. Primatol. 21, 64-68 (1992).

61. Myer, L., Kuhn, L., Stein, Z.A., Wright, T.C. Jr. \& Denny, L. Intravaginal practices, bacterial vaginosis, and women's susceptibility to HIV infection: epidemiological evidence and biological mechanisms. Lancet Infect. Dis. 5, 786-794 (2005). 
62. Schwandt, M., Morris, C., Ferguson, A., Ngugi, E. \& Moses, S. Anal and dry sex in commercial sex work, and relation to risk for sexually transmitted infections and HIV in Meru, Kenya. Sex. Transm. Infect. 82, 392-396 (2006).

63. Weiler, A.M. et al. Genital ulcers facilitate rapid viral entry and dissemination following intravaginal inoculation with cell-associated simian immunodeficiency virus SIVmac239. J. Virol. 82, 4154-4158 (2008).

64. lijima, N., Thompson, J.M. \& Iwasaki, A. Dendritic cells and macrophages in the genitourinary tract. Mucosal Immunol. 1, 451-459 (2008).

65. Wira, C.R., Fahey, J.V., Ghosh, M., Patel, M.V., Hickey, D.K. \& Ochiel, D.O. Sex hormone regulation of innate immunity in the female reproductive tract: the role of epithelial cells in balancing reproductive potential with protection against sexually transmitted pathogens. Am. J. Reprod. Immunol. 63, 544-565 (2010).

66. Hirbod, T. \& Broliden, K. Mucosal immune responses in the genital tract of HIV-1-exposed uninfected women. J. Intern. Med. 262, 44-58 (2007).

67. Brandtzaeg, P. Mucosal immunity: induction, dissemination, and effector functions. Scand. J. Immunol. 70, 505-515 (2009),

68. Pala, P., Gomez-Roman, V.R., Gilmour, J. \& Kaleebu, P. An African perspective on mucosal immunity and HIV-1. Mucosal Immunol. 2, 300-314 (2009).

69. Levinson, P. et al. Levels of innate immune factors in genital fluids: association of alpha defensins and LL-37 with genital infections and increased HIV acquisition. AIDS 23, 309-317 (2009).

70. Li, Q. et al. Glycerol monolaurate prevents mucosal SIV transmission. Nature 458, 1034-1038 (2009).

71. Cremel, M. et al. Characterization of CCL20 secretion by human epithelial vaginal cells: involvement in Langerhans cell precursor attraction. J. Leukoc. Biol. 78, 158-166 (2005).

72. Berlier, W. et al. Seminal plasma promotes the attraction of Langerhans cells via the secretion of CCL20 by vaginal epithelial cells: involvement in the sexual transmission of HIV. Hum. Reprod. 21, 1135-1142 (2006).

73. Genesca, M. et al. Protective attenuated lentivirus immunization induces SIV-specific T cells in the genital tract of rhesus monkeys. Mucosal Immunol. 1, 219-228 (2008).

74. Pahar, B. et al. Single epitope mucosal vaccine delivered via immunostimulating complexes induces low level of immunity against simian-HIV. Vaccine 24, 6839-6849 (2006).

75. Abel, K. et al. Simian-human immunodeficiency virus SHIV89.6-induced protection against intravaginal challenge with pathogenic SIVmac239 is independent of the route of immunization and is associated with a combination of cytotoxic T-lymphocyte and alpha interferon responses. J. Virol. 77, 3099-3118 (2003).

76. Johnson, R.P. et al. Highly attenuated vaccine strains of simian immunodeficiency virus protect against vaginal challenge: inverse relationship of degree of protection with level of attenuation. J. Virol. 73, 4952-4961 (1999).

77. Stone, M. et al. Limited dissemination of pathogenic SIV after vaginal challenge of rhesus monkeys immunized with a live, attenuated lentivirus. Virology 392, 260-270 (2009).

78. Fowke, K.R. et al. Resistance to HIV-1 infection among persistently seronegative prostitutes in Nairobi, Kenya. Lancet 348, 1347-1351 (1996).

79. Saez-Cirion, A., Pancino, G., Sinet, M., Venet, A. \& Lambotte, O. HIV controllers: how do they tame the virus? Trends Immunol. 28, 532-540 (2007).

80. Hatano, H. et al. Evidence for persistent low-level viremia in individuals who control human immunodeficiency virus in the absence of antiretroviral therapy. J. Virol. 83, 329-335 (2009).

81. Deeks, S.G. \& Walker, B.D. Human immunodeficiency virus controllers: mechanisms of durable virus control in the absence of antiretroviral therapy. Immunity 27, 406-416 (2007).

82. Cole, A.M. et al. Retrocyclin: a primate peptide that protects cells from infection by T- and M-tropic strains of HIV-1. Proc. Natl Acad. Sci. USA 99, 1813-1818 (2002).

83. Venkataraman, N. et al. Reawakening retrocyclins: ancestral human defensins active against HIV-1. PLoS Biol. 7, e95 (2009).

84. Towers, G.J. The control of viral infection by tripartite motif proteins and cyclophilin A. Retrovirology 4, 40 (2007).

85. Li, Y., Li, X., Stremlau, M., Lee, M. \& Sodroski, J. Removal of arginine 332 allows human TRIM5alpha to bind human immunodeficiency virus capsids and to restrict infection. J. Virol. 80, 6738-6744 (2006).
86. Pham, Q.T., Bouchard, A., Grutter, M.G. \& Berthoux, L. Generation of human TRIM5alpha mutants with high HIV-1 restriction activity. Gene Ther. 17, 859-871 (2010).

87. Alter, G. \& Altfeld, M. NK cells in HIV-1 infection: evidence for their role in the control of HIV-1 infection. J. Inter. Med. 265, 29-42 (2009).

88. O'Connell, K.A., Han, Y., Williams, T.M., Siliciano, R.F. \& Blankson, J.N. Role of natural killer cells in a cohort of elite suppressors: low frequency of the protective KIR3DS1 allele and limited inhibition of human immunodeficiency virus type 1 replication in vitro. J. Virol. 83, 5028-5034 (2009).

89. Woll, P.S. et al. Human embryonic stem cells differentiate into a homogeneous population of natural killer cells with potent in vivo antitumor activity. Blood 113, 6094-6101 (2009).

90. Ni, Z. et al. Human pluripotent stem cells produce natural killer cells that mediate anti-HIV-1 activity by utilizing diverse cellular mechanisms. J. Virol. 85, 43-50 (2011).

91. Card, C.M., McLaren, P.J., Wachihi, C., Kimani, J., Plummer, F.A. \& Fowke, K.R. Decreased immune activation in resistance to HIV-1 infection is associated with an elevated frequency of CD4(+)CD25(+)FOXP3(+) regulatory T cells. J. Infect. Dis. 199, 1318-1322 (2009).

92. Zhang, Z.Q. et al. Roles of substrate availability and infection of resting and activated CD4+ T cells in transmission and acute simian immunodeficiency virus infection. Proc. Natl Acad. Sci. USA 101, 5640-5645 (2004).

93. Belkaid, Y. \& Tarbell, K. Regulatory T cells in the control of hostmicroorganism interactions. Ann. Rev. Immunol. 27, 551-589 (2009).

94. Devito, C. et al. Mucosal and plasma IgA from HIV-exposed seronegative individuals neutralize a primary HIV-1 isolate. AIDS 14, 1917-1920 (2000).

95. Kaul, R. et al. HIV-1-specific mucosal lgA in a cohort of HIV-1-resistant Kenyan sex workers. AIDS 13, 23-29 (1999).

96. Hirbod, T. et al. HIV-neutralizing immunoglobulin A and HIV-specific proliferation are independently associated with reduced HIV acquisition in Kenyan sex workers. AIDS 22, 727-735 (2008).

97. Horton, R.E. et al. Cervical HIV-specific IgA in a population of commercial sex workers correlates with repeated exposure but not resistance to HIV. AIDS Res. Hum. Retroviruses 25, 83-92 (2009).

98. Kaul, R. et al. HIV-1-specific mucosal CD8+ lymphocyte responses in the cervix of HIV-1-resistant prostitutes in Nairobi. J. Immunol. 164, 1602-1611 (2000).

99. Kaul, R. et al. Late seroconversion in HIV-resistant Nairobi prostitutes despite pre-existing HIV-specific CD8+ responses. J. Clin. Invest. 107, 341-349 (2001).

100. Tudor, D. et al. HIV-1 gp41-specific monoclonal mucosal IgAs derived from highly exposed but lgG-seronegative individuals block HIV-1 epithelial transcytosis and neutralize CD4(+) cell infection: an IgA gene and functional analysis. Mucosal Immunol. 2, 412-426 (2009).

101. Dorrell, L. et al. Absence of specific mucosal antibody responses in HIV-exposed uninfected sex workers from the Gambia. AIDS 14, 1117-1122 (2000).

102. Ghosh, M. et al. Anti-HIV activity in cervical-vaginal secretions from HIVpositive and -negative women correlate with innate antimicrobial levels and IgG antibodies. PloS One 5, e11366 (2010).

103. Mestecky, J., Moldoveanu, Z., Smith, P.D., Hel, Z. \& Alexander, R.C. Mucosal immunology of the genital and gastrointestinal tracts and HIV-1 infection. J. Reprod. Immunol. 83, 196-200 (2009).

104. Zhang, Z. et al. Sexual transmission and propagation of SIV and HIV in resting and activated CD4+ T cells. Science 286, 1353-1357 (1999).

105. Maher, D., Wu, X., Schacker, T., Horbul, J. \& Southern, P. HIV binding, penetration, and primary infection in human cervicovaginal tissue. Proc. Natl Acad. Sci. USA 102, 11504-11509 (2005).

106. Hu, J., Gardner, M.B. \& Miller, C.J. Simian immunodeficiency virus rapidly penetrates the cervicovaginal mucosa after intravaginal inoculation and infects intraepithelial dendritic cells. J. Virol. 74, 6087-6095 (2000).

107. Maher, D.M., Zhang, Z.Q., Schacker, T.W. \& Southern, P.J. ex vivo modeling of oral HIV transmission in human palatine tonsil. J. Histochem. Cytochem. 53, 631-642 (2005).

108. Fox-Canale, A.M. et al. Human cytomegalovirus and human immunodeficiency virus type-1 co-infection in human cervical tissue. Virology 369, 55-68 (2007). 
109. Biancotto, A. et al. Upregulation of human cytomegalovirus by HIV type 1 in human lymphoid tissue ex vivo. AIDS Res. Hum. Retroviruses 24, 453-462 (2008).

110. Smith-McCune, K.K. et al. Type-specific cervico-vaginal human papillomavirus infection increases risk of HIV acquisition independent of other sexually transmitted infections. PloS One 5, e10094 (2010).

111. Gipson, I.K. et al. The amount of MUC5B mucin in cervical mucus peaks at midcycle. J. Clin. Endocrinol. Metab. 86, 594-600 (2001).

112. Lai, S.K. et al. Human immunodeficiency virus type 1 is trapped by acidic but not by neutralized human cervicovaginal mucus. J. Virol. 83, 11196-11200 (2009).

113. Doncel, G.F., Joseph, T. \& Thurman, A.R. Role of semen in HIV-1 transmission: inhibitor or facilitator? Am. J. Reprod. Immunol. 65, 292-301 (2011).

114. Saba, E. et al. HIV-1 sexual transmission: early events of HIV-1 infection of human cervico-vaginal tissue in an optimized ex vivo model. Mucosal Immunol. 3, 280-290 (2010).

115. Grivel, J.C. \& Margolis, L. Use of human tissue explants to study human infectious agents. Nat. Protoc. 4, 256-269 (2009).

116. Li, Q. et al. Visualizing antigen-specific and infected cells in situ predicts outcomes in early viral infection. Science 323, 1726-1729 (2009).

117. Espina, V. et al. Laser-capture microdissection. Nat. Protoc. 1, 586-603 (2006).

118. Churchill, M.J. et al. Extensive astrocyte infection is prominent in human immunodeficiency virus-associated dementia. Ann. Neurol. 66, 253-258 (2009).

119. Hu, Q. et al. Blockade of attachment and fusion receptors inhibits HIV-1 infection of human cervical tissue. J. Exp. Med. 199, 1065-1075 (2004).

120. Buffa, V., Stieh, D., Mamhood, N., Hu, Q., Fletcher, P. \& Shattock, R.J. Cyanovirin-N potently inhibits human immunodeficiency virus type 1 infection in cellular and cervical explant models. J. Gen. Virol. 90, 234-243 (2009).

121. Kumar, R.B., Maher, D.M., Herzberg, M.C. \& Southern, P.J. Expression of HIV receptors, alternate receptors and co-receptors on tonsillar epithelium: implications for HIV binding and primary oral infection. Virol. J. 3, 25 (2006).

122. Poonia, B., Walter, L., Dufour, J., Harrison, R., Marx, P.A. \& Veazey, R.S. Cyclic changes in the vaginal epithelium of normal rhesus macaques. J. Endocrinol. 190, 829-835 (2006).

123. Poonia, B., Wang, X. \& Veazey, R.S. Distribution of simian immunodeficiency virus target cells in vaginal tissues of normal rhesus macaques: implications for virus transmission. J. Reprod. Immunol. 72, 74-84 (2006).

124. Marx, P.A. et al. Progesterone implants enhance SIV vaginal transmission and early virus load. Nat. Med. 2, 1084-1089 (1996).

125. Haaland, R.E. et al. Inflammatory genital infections mitigate a severe genetic bottleneck in heterosexual transmission of subtype A and C HIV1. PLoS Pathog. 5, e1000274 (2009).

126. Wood, N. et al. HIV evolution in early infection: selection pressures, patterns of insertion and deletion, and the impact of APOBEC. PLOS Pathog. 5, e1000414 (2009).

127. Keele, B.F. Identifying and characterizing recently transmitted viruses. Curr. Opin. HIV AIDS 5, 327-334 (2010).

128. Stone, M. et al. A limited number of simian immunodeficiency virus (SIV) env variants are transmitted to rhesus macaques vaginally inoculated with SIVmac251. J. Virol. 84, 7083-7095 (2010).

129. Keele, B.F. et al. Identification and characterization of transmitted and early founder virus envelopes in primary HIV-1 infection. Proc. Natl Acad. Sci. USA 105, 7552-7557 (2008).

130. Miller, C.J. et al. Propagation and dissemination of infection after vaginal transmission of simian immunodeficiency virus. J. Virol. 79, 9217-9227 (2005).

131. Michelini, M., Rosellini, A., Simoncini, T., Papini, S. \& Revoltella, R.P. A three-dimensional organotypic culture of the human uterine exocervix for studying mucosal epithelial differentiation and migrating leukocytes. Differentiation 72, 138-149 (2004).

132. Michelini, M., Rosellini, A., Mandys, V., Simoncini, T. \& Revoltella, R.P. Cytoarchitecture modifications of the human uterine endocervical mucosa in long-term three-dimensional organotypic culture. Pathol. Res. Pract. 201, 679-689 (2005).

133. Glushakova, S., Baibakov, B., Zimmerberg, J. \& Margolis, L.B. Experimental HIV infection of human lymphoid tissue: correlation of
CD4+ T cell depletion and virus syncytium-inducing/non-syncytiuminducing phenotype in histocultures inoculated with laboratory strains and patient isolates of HIV type 1. AIDS Res. Hum. Retroviruses 13, 461-471 (1997).

134. Van Duyne, R. et al. The utilization of humanized mouse models for the study of human retroviral infections. Retrovirology 6, 76 (2009).

135. Denton, P.W. \& Garcia, J.V. Novel humanized murine models for HIV research. Curr. HIVIAIDS Rep. 6, 13-19 (2009).

136. Koyanagi, Y., Tanaka, Y., Ito, M. \& Yamamoto, N. Humanized mice for human retrovirus infection. Curr. Top. Microbiol. Immunol. 324, 133-148 (2008).

137. Kollmann, T.R. et al. Disseminated human immunodeficiency virus 1 (HIV-1) infection in SCID-hu mice after peripheral inoculation with HIV-1. J. Exp. Med. 179, 513-522 (1994).

138. Goldstein, H., Pettoello-Mantovani, M., Katopodis, N.F., Kim, A., Yurasov, S. \& Kollmann, T.R. SCID-hu mice: a model for studying disseminated HIV infection. Semin. Immunol. 8, 223-231 (1996).

139. Wege, A.K., Melkus, M.W., Denton, P.W., Estes, J.D. \& Garcia, J.V. Functional and phenotypic characterization of the humanized BLT mouse model. Curr. Top. Microbiol. Immunol. 324, 149-165 (2008).

140. Denton, P.W. et al. Antiretroviral pre-exposure prophylaxis prevents vaginal transmission of HIV-1 in humanized BLT mice. PLOS Med. 5, e16 (2008).

141. Ayehunie, S. et al. Organotypic human vaginal-ectocervical tissue model for irritation studies of spermicides, microbicides, and feminine-care products. Toxicol. In Vitro 20, 689-698 (2006).

142. Mesquita, P.M. et al. Disruption of tight junctions by cellulose sulfate facilitates HIV infection: model of microbicide safety. J. Infect. Dis. 200, 599-608 (2009).

143. Bouschbacher, M. et al. Early events in HIV transmission through a human reconstructed vaginal mucosa. AIDS 22, 1257-1266 (2008).

144. Oliva, R., de Mateo, S. \& Estanyol, J.M. Sperm cell proteomics. Proteomics 9, 1004-1017 (2009).

145. Brewis, I.A. \& Gadella, B.M. Sperm surface proteomics: from protein lists to biological function. Mol. Hum. Reprod. 16, 68-79 (2010).

146. Kay, V.J. \& Robertson, L. Hyperactivated motility of human spermatozoa: a review of physiological function and application in assisted reproduction. Hum. Reprod. Update 4, 776-786 (1998).

147. De Jonge, C. Biological basis for human capacitation. Hum. Reprod. Update 11, 205-214 (2005).

148. Johanisson, E., Campana, A., Luthi, R. \& de Agostini, A. Evaluation of 'round cells' in semen analysis: a comparative study. Hum. Reprod. Update 6, 404-412 (2000).

149. Anderson, D.J., Politch, J.A., Martinez, A., Van Voorhis, B.J., Padian, N.S. \& O'Brien, T.R. White blood cells and HIV-1 in semen from vasectomised seropositive men. Lancet 338, 573-574 (1991).

150. el-Demiry, M.I., Hargreave, T.B., Busuttil, A., James, K. \& Chisholm, G.D. Identifying leucocytes and leucocyte subpopulations in semen using monoclonal antibody probes. Urology 28, 492-496 (1986).

151. Bezold, G., Politch, J.A., Kiviat, N.B., Kuypers, J.M., Wolff, H. \& Anderson, D.J. Prevalence of sexually transmissible pathogens in semen from asymptomatic male infertility patients with and without leukocytospermia. Fertil. Steril. 87, 1087-1097 (2007).

152. Coombs, R.W. et al. Lower genitourinary tract sources of seminal HIV. J. Acquir. Immune Defic. Syndr. 41, 430-438 (2006).

153. Dejucq, N. \& Jegou, B. Viruses in the mammalian male genital tract and their effects on the reproductive system. Microbiol. Mol. Biol. Rev. 65, 208-231; (2001).

154. Maegawa, M. et al. A repertoire of cytokines in human seminal plasma. J. Reprod. Immunol. 54, 33-42 (2002).

155. Denison, F.C., Grant, V.E., Calder, A.A. \& Kelly, R.W. Seminal plasma components stimulate interleukin-8 and interleukin-10 release. Mol. Hum. Reprod. 5, 220-226 (1999).

156. Kelly, R.W., Carr, G.G. \& Critchley, H.O. A cytokine switch induced by human seminal plasma: an immune modulation with implications for sexually transmitted disease. Hum. Reprod. 12, 677-681 (1997).

157. Kelly, R.W. \& Critchley, H.O. Immunomodulation by human seminal plasma: a benefit for spermatozoon and pathogen? Hum. Reprod. 12, 2200-2207 (1997).

158. Politch, J.A., Tucker, L., Bowman, F.P. \& Anderson, D.J. Concentrations and significance of cytokines and other immunologic factors in semen of healthy fertile men. Hum. Reprod. 22, 2928-2935 (2007). 
159. Huleihel, M., Lunenfeld, E., Levy, A., Potashnik, G. \& Glezerman, M. Distinct expression levels of cytokines and soluble cytokine receptors in seminal plasma of fertile and infertile men. Fertil. Steril. 66, 135-139 (1996).

160. Bozzini, S. et al. Heparin-binding domain of human fibronectin binds HIV-1 gp120/160 and reduces virus infectivity. J. Med. Virol. 54, 44-53 (1998).

161. Bounou, S., Leclerc, J.E. \& Tremblay, M.J. Presence of host ICAM-1 in laboratory and clinical strains of human immunodeficiency virus type 1 increases virus infectivity and CD4(+)-T-cell depletion in human lymphoid tissue, a major site of replication in vivo. J. Virol. 76, 1004-1014 (2002).

162. Cantin, R., Methot, S. \& Tremblay, M.J. Plunder and stowaways: incorporation of cellular proteins by enveloped viruses. J. Virol. 79, 6577-6587 (2005).

163. Cone, R.A. Barrier properties of mucus. Adv. Drug Deliv. Rev. 61, 75-85 (2009).

164. Suarez, S.S. \& Pacey, A.A. Sperm transport in the female reproductive tract. Hum. Reprod. Update 12, 23-37 (2006).

165. Settlage, D.S., Motoshima, M. \& Tredway, D.R. Sperm transport from the external cervical os to the fallopian tubes in women: a time and quantitation study. Fertil. Steril. 24, 655-661 (1973).

166. Wilcox, A.J., Weinberg, C.R. \& Baird, D.D. Timing of sexual intercourse in relation to ovulation. Effects on the probability of conception, survival of the pregnancy, and sex of the baby. N. Engl. J. Med. 333, 1517-1521 (1995).

167. Perloff, W.H. \& Steinberger, E. In vivo survival of spermatozoa in cervical mucus. Am. J. Obstet. Gynecol. 88, 439-442 (1964).

168. Nuovo, G.J., Becker, J., Simsir, A., Margiotta, M., Khalife, G. \& Shevchuk, M. HIV-1 nucleic acids localize to the spermatogonia and their progeny. A study by polymerase chain reaction in situ hybridization. Am. J. Pathol. 144, 1142-1148 (1994).

169. Ceballos, A. et al. Spermatozoa capture HIV-1 through heparan sulfate and efficiently transmit the virus to dendritic cells. J. Exp. Med. 206, 2717-2733 (2009).

170. Pudney, J., Nguyen, H., Xu, C. \& Anderson, D.J. Microscopic evidence against HIV-1 infection of germ cells or attachment to sperm. J. Reprod. Immunol. 44, 57-77 (1999).

171. Davidson, J.B. \& Douglas, G.C. Modulation of integrin function inhibits HIV transmission to epithelial cells and fertilization. J. Reprod. Immunol. 41, 271-290 (1998).

172. Geijtenbeek, T.B. et al. DC-SIGN a dendritic cell-specific HIV-1-binding protein that enhances trans-infection of T cells. Cell 100, 587-597 (2000).

173. Sabatte, J. et al. Human seminal plasma abrogates the capture and transmission of human immunodeficiency virus type 1 to CD4+ T cells mediated by DC-SIGN. J. Virol. 81, 13723-13734 (2007).

174. Stax, M.J. et al. Mucin 6 in seminal plasma binds DC-SIGN and potently blocks dendritic cell mediated transfer of HIV-1 to CD4(+) Tlymphocytes. Virology 391, 203-211 (2009).
175. Munch, J. et al. Semen-derived amyloid fibrils drastically enhance HIV infection. Cell 131, 1059-1071 (2007).

176. Roan, N.R. et al. The cationic properties of SEVI underlie its ability to enhance human immunodeficiency virus infection. J. Viro/ 83, 73-80 (2009).

177. Kim, K.A. et al. Semen-mediated enhancement of HIV infection is donordependent and correlates with the levels of SEVI. Retrovirology 7, 55 (2010).

178. Sharkey, D.J., Macpherson, A.M., Tremellen, K.P. \& Robertson, S.A. Seminal plasma differentially regulates inflammatory cytokine gene expression in human cervical and vaginal epithelial cells. Mol. Hum. Reprod. 13, 491-501 (2007).

179. Scofield, V.L. Sperm as infection-potentiating cofactors in HIV transmission. J. Reprod. Immunol. 41, 359-372 (1998).

180. Robertson, S.A. Seminal plasma and male factor signalling in the female reproductive tract. Cell Tissue Res. 322, 43-52 (2005).

181. Maher, D., Wu, X., Schacker, T., Larson, M. \& Southern, P. A model system of oral HIV exposure, using human palatine tonsil, reveals extensive binding of HIV infectivity, with limited progression to primary infection. J. Infect. Dis. 190, 1989-1997 (2004).

182. Andrei, G. Three-dimensional culture models for human viral diseases and antiviral drug development. Antiviral Res. 71, 96-107 (2006).

183. Richardson-Harman, N. et al. Multisite comparison of anti-human immunodeficiency virus microbicide activity in explant assays using a novel endpoint analysis. J. Clin. Microbiol. 47, 3530-3539 (2009).

184. Madan, R.P. et al. Molecular umbrellas: a novel class of candidate topical microbicides to prevent human immunodeficiency virus and herpes simplex virus infections. J. Virol. 81, 7636-7646 (2007).

185. Southern, P., Horbul, J., Maher, D. \& Davis, D.A. C. albicans colonization of human mucosal surfaces. PloS One 3, e2067 (2008).

186. Neofytou, E., Sourvinos, G., Asmarianaki, M., Spandidos, D.A. \& Makrigiannakis, A. Prevalence of human herpes virus types 1-7 in the semen of men attending an infertility clinic and correlation with semen parameters. Fertil. Steril 91, 2487-2494 (2009).

187. Mclver, C.J. et al. MultiplexPCR testing detection of higher-thanexpected rates of cervical mycoplasma, ureaplasma, and trichomonas and viral agent infections in sexually active Australian women. J. Clin. Microbiol. 47, 1358-1363 (2009).

188. Asin, S.N., Fanger, M.W., Wildt-Perinic, D., Ware, P.L., Wira, C.R. \& Howell, A.L. Transmission of HIV-1 by primary human uterine epithelial cells and stromal fibroblasts. J. Infect. Dis. 190, 236-245 (2004).

189. Goonetilleke, N. et al. The first T cell response to transmitted/founder virus contributes to the control of acute viremia in HIV-1 infection. J. Exp. Med. 206, 1253-1272 (2009).

190. Estes, J.D. et al. Premature induction of an immunosuppressive regulatory $T$ cell response during acute simian immunodeficiency virus infection. J. Infect. Dis. 193, 703-712 (2006).

191. Nathan, C. Neutrophils and immunity: challenges and opportunities. Nat. Rev. Immunol. 6, 173-182 (2006). 